\title{
Hannah Arendt's Hidden Phenomenology of the Body
}

\section{Charles des Portes ${ }^{1}$ iD}

Accepted: 17 November 2021 / Published online: 9 December 2021

(c) The Author(s) 2021

\begin{abstract}
Amongst the Arendtian scholars, there is almost a consensus on Arendt's supposedly reluctance to the question of the body. The Arendtian body is said to belong to the unpolitical realm of necessity, in other words, the body is a private matter that should not appear in public. It is antipolitical. However, in this paper, I want to suggest that there is a possibility to outline a phenomenology of embodied political action in what I think to be Arendt's hidden phenomenology of the body. To make my point, I will first show that what the scholars call the Arendtian body is in fact an Arendtian Body. Secondly, in the German version of The Human Condition, Arendt surprisingly used the Heideggerian term Befindlichkeit (disposition) that, I will argue, outline the basis of a political phenomenology of the body in Arendt's work. More precisely, I will try to show that political action is embodied, that there is a hexis, a pathos and an ethos of action.
\end{abstract}

Keywords Hannah Arendt $\cdot$ Phenomenology $\cdot$ Hermeneutics $\cdot$ Body $\cdot$ Political philosophy

Hannah Arendt's status as a major political theorist of the twentieth century has gained her an important amount of, sympathetic or not, secondary literature on her work. Amongst this corpus, one of the leading trend is, to use Claude Lefort's formula, to think "with and against Hannah Arendt" (Lefort, 2002). This motto was also invested by Seyla Benhabib to highlight the importance and relevancy of Arendt's work, as well as to point out her tendency to make distinctions. Thinking "With Arendt, Contra Arendt" (Benhabib, 2003: 123) is a way to use her art of making distinction in order to subvert them. In the Arendtian distinctions, the more commented and still criticized are the political/social and public/private ones. According to the critics, these distinctions are "dichotomies" (Benhabib, 2003: 124), or two antagonist categories. Indeed, the private is what should not appear in public, and the social is what is not political even if it is expressed in public. The categories

Charles des Portes

C.desPortes@leeds.ac.uk

1 University of Leeds, Leeds, United Kingdom 
are supposedly exclusive to each other. At the heart of the private/public and social/ political distinctions lie the question I will discuss in this article, namely, the one of the body. According to Arendt, the body is what should not appear in public, what should stay in the private realm. The crisis of Modernity that Arendt identified with what she called the rise of the social, is best illustrated by the publicity of private matters such as the necessity of the body. Accordingly, the more and less sympathetic scholars such as Connolly, Tierney or Honig agreed on Arendt's supposedly reluctance to the question of the body. As Bonnie Honig put it, "[t]he human body is, for Hannah Arendt, a master signifier of necessity, irresistibility, imitability, and the determination of pure process" (1992: 217). Hence, the body is submitted to the biological life-process, when we are driven by our biological body we cannot act in public because we have to be liberated from the necessity of life in order to appear in public.

However, in this article, I will argue that these criticisms of the Arendtian body are misled for two main reasons. First, they give an account of an Arendtian body, while I will argue that the Arendtian body is actually multifold. Second, they do not take into account, what I believe to be Arendt's philosophical approach. A hermeneutic phenomenology, which, following Heidegger, has for its first step the deconstruction (Abbau) of the metaphysical tradition. Indeed, Arendt claimed to be part of those who "have been attempting to dismantle metaphysics" (Arendt, 1978: 212). In this article, I follow Sophie Loidolt and Marieke Borren, amongst others, in their work to (re)place Arendt within the field of phenomenology. Hannah Arendt herself said, she was "a sort of phenomenologist" (Young-Bruehl, 1984: 405). My aim is, then, to contribute to the discussions about Hannah Arendt's phenomenology. I will support the hypothesis that there is a hidden or implicit phenomenology of the body in her work which leads to her view on the embodiment of action, then, of the political. To make my point, I will first address some of the main critiques of the Arendtian body in order to show that the biological/laboring body is not the only body on which Arendt has something to say. Thereafter, I will show that a more precise account of her phenomenology of the body can be found in the German version of The Human Condition, where she used the Heideggerian term Befindlichkeit-that she translated by 'identity' in the English version. Finally, I will outline the basis of her understanding of the embodiment of action by showing that there is a hexis and an ethos of action, the latter being the embodiment of what Arendt calls the principles of action.

\section{The Arendtian (Biological) Body}

In The Human Condition, Hannah Arendt analyzed the question of the body when she discussed the laboring activity. According to her, the human condition is divided into three activities, labor, work and action. Work is the activity of the craftmanship, a means-end activity which produces the objects that are in the world. Action is the political activity par excellence, where people appear before others in public through deed and speech. Labor is the activity "which corresponds to the biological process of the human body" (Arendt, 1998: 7). 
Therefore, the natural process of life which is located in the body needs the product of labor to regenerate the life process. We produce and consume in order to stay alive. Then, this is a claim about the biological or the laboring body, and it is precisely this body that is accounted as the Arendtian body, or the only Arendtian understanding of the body. This body cannot appear in public, because politics cannot be the realm of necessities, as " $[\mathrm{t}]$ he distinctive trait of the household sphere was that in it men lived together because they were driven by their wants and needs" (Arendt, 1998: 30).

As Thomas Tierney put it, the problem for Arendt is "that this privative dimension of privacy has been lost in modernity, that the private is no longer the realm of subhuman, slavish activity" (1993: 16). Indeed, with the rise of the social, what was before private-for the Greeks-became public. Some critics reproached to Arendt her tendency to "treat the body as a hindrance or inconvenience to public life" (Tierney, 1993: 40). To put it differently, she is accused to praise the Greek account of the body against the Modern introduction of the body in public. This critique is well addressed by William Connolly in his text A critique of pure politics (1997). Just like Kant instated a purity in his morality, Arendt reinstated "a corollary model of purity inside the political 'realm' itself" (Connolly, 1997: 15). For Connolly, this Arendtian temptation of purity is partly marked by "her depreciation of 'the body" in ethics and politics" (1997: 15). He reproached her to be blind to the liberation from the bodily necessities as a political question. What is at stake there is her supposedly sharp distinction between the social and the political. While for the Greeks, the liberation from the household, then from the bodily necessity, was made possible by owning slaves, with Modernity and the rise of the social, society became a big household, then, private-unpolitical-matters are made public. However, for Connolly, the body has a political value and can be the object of political action. According to him, Arendt failed "to engage the micro-politics by which those thought-imbued feelings of anxiety, disgust, resentment, responsiveness and generosity that enter so profoundly into private and public ethics, are shaped" (Connolly, 1997: 18) because she maintained the biological body out of the political realm. Therefore, she missed the sensibility of the body that could be made into a political object. However, as Liesbeth Schoonheim argued, by his attempt to make the Arendtian body unidimensional or univocal, Connolly "is liable to the same criticism [...as] he posits a body that is univocal and subordinate to politics" (2019: 481; my emphasis). Yet, Arendt argued against the submission of the body to politics, she "objects to the fact that some corporeal dimensions are objects of political action" (Schoonheim, 2019: 480). Hence, it means, that emotions or anything related to the biological body is not an object of the political. However, it does not mean that the political cannot be embodied. Indeed, for her, the necessity of the body is not something that one could be liberated from by politics.

What is mostly missed by the critiques of the Arendtian body is her own philosophical approach, namely a hermeneutic phenomenology. Following Heidegger, Arendt argued that humans are hermeneutic beings, which means that understanding is not what they do, but what they are. It is "the specifically human way of being alive" (Arendt 1994: 308). Actually, as some defended (Loidolt, 2018; Borren, 2010; Villa, 1995; amongst others), Hannah Arendt's philosophical approach is indebted, 
to a certain extent, to Heidegger. This paper will follow this direction, even if I will also acknowledge the differences between the two thinkers. ${ }^{1}$

In a grant application to the Rockefeller Foundation for her book Between Past and Future (2006), Hannah Arendt described her intention as twofold, "first, a critical examination of the chief traditional concepts and conceptual frameworks of political thinking [...] to find out where these concepts came from before they become like worn-out coins and abstract generalizations". Therefore, she proposes to "examine the concrete historical and generally political experiences which gave rise to political concepts. For the experience behind even the most worn-out concepts remain valid and must be recaptured and reactualized" (Young-Bruehl, 1984: 325). Here there is a similarity with Heidegger's task of deconstruction of metaphysics. Arendt did not present her method as a negative enterprise of debunking but rather, like Heidegger, ${ }^{2}$ she uses this method for a creative appropriation of what have been transmitted by the tradition of political thought which, according to her, starts with Plato and ends with Marx (Arendt, 2005: 38). In the preface of Between Past and Futures, she presented all the chapters of the book as "exercises [which] move between past and future, [which] contain criticism as well as experiment" (Arendt, 2006: 14; my emphasis). However, these two steps are not antagonistic as "there is an element of experiment in the critical interpretation of the past" (Arendt, 2006: 14). Therefore, as Marieke Borren (2010) explained, Hannah Arendt's hermeneutic phenomenology is committed to a deconstruction of the concepts from the metaphysical tradition and an experimentation of these concepts through what has been forgotten over time and is absent from the tradition. In other word, to understand a phenomenon means to depart ourselves from metaphysics so that we do not subsume the new under old categories. And this is precisely what, I think, Arendt did with the concept of the body. I believe that one cannot have a fair view of Arendt's understanding of the body without taking her philosophical approach under consideration.

In his critique of Arendt's account of the body, Tierney holds that her view on the body blinded her interpretation of the Greeks' and Christians' tradition of thought. However, I think this is a misunderstanding of what Arendt is doing while discussing the tradition. Whether Arendt's account of Christianity is accurate or not is not the issue here. Tierney accused Arendt of subsuming her interpretation of the tradition under her account of what the body is. Yet, according to her philosophical approach, I suggest to analyze her attempt to discuss the tradition as part of her deconstruction of metaphysics. Indeed, she does not advocate a Greek account of the body against the Christian one, rather, she tries to analyze what role does the body play in the metaphysical tradition. In the following paragraphs, I will show that it is fruitful to read Arendt's discussion about the body in the tradition as a critique

\footnotetext{
1 For Arendt's critique of Heidegger's philosophy, see her text What is Existential Philosophy in Essays in Understanding (Arendt, 1994).

2 See Heidegger, Being and Time $§ 6 \mathrm{f}$. (1962), for a discussion of his hermeneutic method of deconstruction.
} 
of the attempt to be liberated from the necessities of body. I will argue that, for her, the biological body cannot be mastered.

Marieke Borren put that Arendt's deconstruction takes the shape of a genealogy (2010: 28; see also Taminiaux, 1997: 199). However, I would go further and say that her genealogy is actually twofold. In Arendt's words, the chief aim of interpretation "is to discover the real origins of traditional concepts in order to distill from them anew their original spirit" (Arendt, 2006: 14). It is precisely in this search for the 'original spirit' that the twofoldness of her genealogy comes. First, Arendt aims at bringing the concept to its origin, which means its creation-most of the time in Greek philosophy-like she does, for instance, with authority (Arendt, 2006: 91-141) or with action in The Human Condition (1998). Moreover, Arendt stated in her grant application for the Rockefeller Foundation that she wants to examine the experiences that gave rise to the political concepts. Therefore, the second step of her deconstruction is to find the ground of a concept, namely the original experience from where it arose. It is, in a certain way, also a reconstruction. This is why, she refers a lot to the pre-philosophical Greek experiences, notably when she mentions Homer. It is what Heidegger called "the birth certificate" (1968: 44) of the concept.

When Hannah Arendt is discussing the body in The Human Condition, she first refers to the Greek experience. In her interpretation of the Greeks, the body was considered as subhuman, it was the body and its necessity that separated them from immortality. Biological life was considered less than human and suicide was esteemed higher than being enslaved, as being enslaved meant to be subjected to the necessity of life. However, a means to escape or to master the biological body was to own slaves in order to move freely in the public space. Suicide was seen as a more noble act because the slave "served only life's necessities and submitted to the compulsion of his master because he wanted to stay alive at all costs" (Arendt, 1998: 316). Moreover, for the Greeks, immortality was achieved by doing great deeds that could be remembered. Yet, the philosophical tradition understood that the biological body was part of the human condition, of the vita activa. More precisely, "[t] he death of Pericles and the Peloponnesian War mark the moment when the men of thought and the men of action began to take different paths" (Arendt, 1998: 17f.). This path was opened by the philosophers, arguably by Socrates himself, who found a higher principle than the one of the polis where immortality is achievable. Thus, something new replaced the mortal body/immortal action dichotomy. This shift from the men of action to the men of thought is illustrated by the distinction between immortality and eternity. The thinker, by leaving the vita activa, enters the vita contemplativa which is the realm where eternity can be experienced. As Arendt explained, this is the reason why Socrates never wrote down his thoughts, because at "the moment he sits down to write his thoughts he ceases to be concerned primarily with eternity," rather, she follows, "[h]e has entered the vita activa and chosen its way of permanence and potential immortality" (1998: 20). Therefore, while for the Greeks, the distinction was between the laboring body and the immortality of work, deed and speech, in the philosophical tradition since Plato, the immortality is not a concern anymore. Rather, the distinction is between the vita activa and the vita contemplativa as the realm of eternity, where one withdraws from the world in order to think. In the Phaedo, Plato argued that philosophy was a way to detach ourselves 
from our body. It is precisely our body that stops us from going to the eternal realm of ideas (Plato, 1969: 49, 66d5). This dualism between the body and the soul is part of what Arendt called metaphysical fallacies (1978: 12), and more precisely, the two world theory which is the separation between the sensible world or the world of appearance and the intelligible world where the truthfulness of things can be found. In the Gorgias, Plato discussed the nature of the soul. Socrates tells us that the soul is constituted by an intelligible part, the noûs, which is corrupted by the sensible world. As Socrates put it, "our body is a tomb" (Plato, 1969: 275, 493a) for our soul because it is what relates us to the sensible world. Therefore, the body must be mastered by the soul. For Plato, philosophy is a way to achieve this as it represents the death of the body. In other words, "the philosopher frees his soul from association with the body" (Plato, 1969: 47, 65a). Hence, Plato's dualism is an attempt to master the body in order to attain the sky of ideas.

If I decide to focus on the question of the body, what is at play, in the metaphysical tradition for Arendt, is the attempt to master the body. This critique can be found in Arendt's discussion of Christianity and Modernity as well. When discussing Augustine, Arendt highlighted that the body was subjected to the mind by the will, which is an organ of the mind. Although Augustine did not make a separation between the body and the mind such as "the death of the body, the separation of the soul from the body, is not good for anyone" (2003, XIII: 6). In order to maintain the unity between the body and the soul, the body must be mastered by the soul as death is the end of this unity. Thus, Christians's concern for life is higher than for the Greeks. Moreover, even when Augustine talked about the eternal resurrected body, he emphasized this relationship, as "the spiritual flesh will thus be subject to the spirit" (2003, XXII: 21), a body "which will be completely subdued to the spirit, will receive from the spirit all that it needs for its life, and will need no other nourishment" (Augustine, 2003, XXII: 25). Here again, there is an attempt to master the body. However, for Hannah Arendt, "it depends upon labor to produce whatever is necessary to keep the human organism alive" (2018: 786). It means that labor is a condition for the biological body to work, however, the body cannot be mastered since "laboring always moves in the same circle prescribed by the living organism" (Arendt, 2018: 795). Thus, the biological body cannot be mastered precisely because the laboring activity is subjected to it.

Therefore, what has been criticized as the Arendtian body is her attempt to describe the living organism as a body that cannot be mastered. Indeed, whether it is the subjection of the body over the soul for Plato, the subjection of the body over the will for Augustine, or the subjection of the body over politics during modernity, these attempts are metaphysical fallacies precisely because the biological necessities that emanate from the body will always remain until our death. In the next section, I will show that there are Arendtian bodies, as the biological body is not Arendt's only endeavor to discuss the body. 


\section{The Arendtian Bodies}

In the following paragraphs, I will analyze the phenomenal structure of the Arendtian bodies. First, what could be said about a non-biological or non-laboring body could be related to her view on labor as a means-end activity. Indeed, labor is the means to fill the biological needs of the body. The movement of the laboring body is cyclical (Arendt, 1998: 96). As Linda Zerilli put it, the movement of the body, for Arendt, is "generic, uniform, univocal, a virtual prison-house. Nothing is less common, less communicable, less public than the body" (1995: 189). However, even if Zerilli was here talking about what is, for her, the Arendtian account of the body, as I showed above, it is referring to the biological body. Then, what could be a possible account of a communicable, public and non-generic, in other words political, body in Arendt's thought? According to Margaret Betz-Hull, a close reading of Arendt's political theory shows that for her, "the body does represent more than a mere mute motivation" (2002: 161). In The Human Condition, Arendt stressed that "the origin of the early reproach of busybodiness (polypragmosyne) leveled against those who spent their live in politics" in "[t]he time-honored resentment of the philosopher against the human condition of having a body" (1998: 16f.). In Arendt's thought, the body has another role in the human condition, namely the appearing body that "functions as a vehicle of the speech and deeds of political action" (Betz-Hull, 2002: 162). When Arendt states that "being and appearing coincide" (1978: 19), she means that the reality of something depends on its appearance in the world, in front of others. Therefore, she outlines a possible role that the body could play in her theory of action. She emphasized this latter point in her critique of the Cartesian res cogitans for being bodyless (Arendt, 1978: 48). By that, she meant that we are always in the world, that the body cannot be separated from the mind. For her, reality cannot be accounted without appearances, without the activity of perception. Moreover, this is precisely on this notion of appearance that her political phenomenology relies on. ${ }^{3}$

As I said previously, Hannah Arendt is concerned with lived experience and she aims to understand the meaning of a phenomenon which cannot be subsumed under a pre-existent category. For Arendt, every political phenomenon needs to be understood in its novelty, this is why the new cannot be subsumed under the old. She stated that every appearance in public is like a second birth, a contingency that brings novelty into the world and that cannot be described by a means-end instrumental model of politics (Arendt, 1998: 176). Within the very performance of action, the actors express their 'who-ness,' who they are and not their 'what-ness,' what they are (Arendt, 1998: 179). From a political perspective, Arendt is not concerned with the empirical data that describe the identity of someone. Rather, who someone is, is a manifestation of a political identity within the very performance of action. In other words, it reveals the "unique distinctness" of someone (Arendt, 1998: 176; my emphasis). Men's ${ }^{4}$ distinctness "are the modes in which human

\footnotetext{
3 See Arendt (1978, 1998: 175-243), Marieke Borren (2010), Sophie Loidolt (2018).

4 I use the masculine when I am directly referring to Arendt's arguments and quotes. I use 'men and women' or 'they/them' for my own arguments.
} 
beings appear to each other, not indeed as physical objects, but qua men," this type of appearance, Arendt follows, is "distinguished from mere bodily existence" (Arendt, 1998: 176). Here, she makes a distinction between a political appearance and the laboring body. The laboring body does not know distinctness because its cyclic process is the same for everyone. However, the way we appear before others in public is distinct. This statement could be related to Merleau-Ponty when he argued that the lived body is not an object, "je ne suis pas devant mon corps, je suis dans mon corps, ou plutôt je suis mon corps. [I am not in front of my body, I am in it, or rather, I am it]" (Merleau-Ponty, 2010: 834). When Merleau-Ponty explained that 'I am my body,' it means, from an Arendtian perspective, that our distinctness is necessarily embodied. Furthermore, it refers to the distinction I have made between the body as an object and embodiment. When the body is taken as an object, its appearance is submitted to a model of analysis. In other words, I already or instantly know what this object/body is. However, if a phenomenon is embodied and appears in public, then, this embodiment is a disclosure that is yet to be discovered or understood. Therefore, to follow Arendt's formula that 'being and appearing coincide,' the distinct body which appears before others reveals who someone is and not only what someone is. The what-ness of someone is the result of the knowledge of a body as an object for empirical sciences. Every time we appear in public, it is "like a second birth, in which we confirm and take upon ourselves the naked fact of our original physical appearance" (Arendt, 1998: 176f.). Thus, we are the embodiment of something new. We insert ourselves into the human world and this insertion "is not forced upon us by necessity, like labor, and it is not prompted by utility, like work" (Arendt, 1998: 177). Accordingly, I stress that there is not an Arendtian body but the possibility of Arendtian bodies. Every human activity has, I hypothesize, a specific mode of embodiment. Moreover, each embodiment is conditioned. The laboring body is conditioned by necessity, the homo faber or the working body is conditioned by utility and the political body "may be simulated by the presence of others [...], but it is never conditioned by them" (Arendt, 1998: 177). Rather, "its impulse springs from the beginning which came into the world when we were born and to which we respond by beginning something new on our own initiative" (Arendt, 1998: 177). Yet, it does not tell precisely what are the hypothetical conditions for the embodiment of politics.

For Hannah Arendt, politics regroups simultaneously what she described as two human conditions, namely natality and plurality.

If action as beginning corresponds to the fact of birth, if it is the actualization of the human condition of natality, then speech corresponds to the fact of distinctness and is the actualization of the human condition of plurality, that is, of living as distinct and unique being among equals.

(Arendt, 1998: 178)

Now, I will highlight the relationship between embodiment, natality and plurality. Indeed, because they are the conditions of politics, to look at their possible embodiment is necessary to explore my hypothesis of the embodiment of action.

Regarding speech, it seems obvious that one needs a body in order to speak and express their distinctness. Political embodiment seems conditioned to natality 
and plurality that both rely on two political activities which are action and speech. Nevertheless, the question of how politics is precisely embodied remains. What is underpinned here is the question of the who-ness, how is a who embodied in a certain way that it is not a what. An exemplification of this distinction could be found in Merleau-Ponty's Phénoménologie de la perception when he mentioned Phaedra. More precisely, he held that "l'actrice devient invisible et c'est Phèdre qui apparaît [the actress becomes invisible and it is Phaedra who appears]" (Merleau-Ponty, 2010: 870). Here the distinction between the actress and Phaedra can be assimilated to the one Arendt made between what-ness and who-ness. Indeed, the what-ness of someone is a general role that someone has in society, a social status that can be rooted in an empiricity or not. It is a general category that does not acknowledge the necessary distinctness of the who-ness. On the other hand, being Phaedra means to be distinguished from the other actresses. The latter becomes invisible when the former appears because the embodied-who appears in place of the generic embodied-what. Through her performance, the actress shows her distinctness. Because the what-ness could be assimilated to a social status, it is a fixed category that remains out of the space of appearance. However, the who-ness exists only in a specific space of appearance, where who someone is can be disclosed to others. Therefore, the distinctness of Phaedra as the who-ness of the actress is conditioned to a space of appearance, which is theater in this example. Accordingly, I put that the whatness does not have a specific embodiment, or, at least, is not directly conditioned to it, while the who-ness is characterized by its embodiment. By this, I mean that the distinctness of the what-ness is more generic, it is a category like gender. In other words, the perception of a what-ness is produced by a social category.

Consequently, an Arendtian understanding of the embodiment of distinctness is not just that 'one needs a body in order to speak'. Rather, it is that the distinctness is an embodiment. Phaedra is distinct from another actress because of the speaking performance. The actress becomes invisible, then silent, and it is Phaedra who appears, through deed and speech. Put together, the deed and speech are what reaffirm the contingency, in other words, the distinctive newness of the who. However, if the relationship between who-ness and novelty seems clearer now, what about the question of plurality, one of Arendt's condition of politics.

As Hannah Arendt had it, the "revelatory quality of speech and action comes to the force where people are with others [...] that is, in sheer human togetherness" (1998: 180; Arendt's emphasis). Togetherness is a condition of appearance as we cannot appear for ourself. It would mean that our body has become an object that appears before us. Merleau-Ponty explained that an object is not always available to me while my body is, as it is always with me. Each of my actions, even the most ordinary ones, are embodied (Merleau-Ponty, 2010: 769). Thus, both the who-ness and the what-ness are embodied, but the former is, in order to show its distinctness to others. According to Arendt, this togetherness, this plurality, is a web of relationships. "Action and speech go on between men," it is an in-between that "owes its origin exclusively to men acting and speaking directly to one another" (Arendt, 1998: 182f., her emphasis). In others words, I can disclose my who-ness only amongst others. 
Here, I built a hypothetical account of what the Arendtian bodies could by putting together Arendt's formula of 'being and appearing coincide' and Merleau-Ponty's phenomenology of the body. However, it remains a hypothesis since there is, apparently, no evidence of Arendt's embodied action or about the embodied-who. To a certain extent, she gave clues about this possibility of embodiment when she stated that speech is bound to the existence of a living body (Arendt, 1998: 183). Yet, it seems, again, to be a reference to the biological body. This is why, in the following section, I aim to evidence an Arendtian account of embodiment that does not refer to the biological body as such.

\section{Identity as Befindlichkeit}

As it is often the case in Arendt's work, when an ambiguity seems to obscure what she means, a way to bypass this is to have a look at the German version of the book. In the case of The Human Condition, Arendt wrote both the English and German version. In Vita Activa, ${ }^{5}$ Arendt sometimes uses the Heideggerian word Befindlichkeit that she translated as identity in The Human Condition. I suggest that this word is a direct reference to Heidegger as The Human Condition "grew right out of the days in Marburg and so in all respects indebted to [Heidegger]" (Benhabib 2003: 117). In this section, I will first showcase the Arendtian use of this word, thereafter, I will focus on the meaning Heidegger gave to this concept that he coined. This will outline the possibility of Arendt's phenomenology of embodied action.

Hannah Arendt used the word identity as a translation of Befindlichkeit under the chapter on Action in The Human Condition, and, more precisely, in the paragraph called The Greek Solution or Der griechische Ausweg aus den Aporien des Handelns (the Greek way out of the aporias of action). Here, Befindlichkeit refers to the "unchangeable identity [bleibende Befindlichkeit] of the person, though disclosing itself intangibly in act and speech, becomes tangible only in the story of the actor's and speaker's life" (Arendt 1998: 193). Befindlichkeit is the human essence as "the essence of who somebody is" (Arendt 1998: 193; my emphasis). However, as Arendt stated, for the Greeks, this essence can only come into being "when life departs, leaving behind nothing but a story" (1998: 193). Moreover, she described this 'unchangeable identity' as an eudaimonia, a Greek word that means 'wellbeing' and that she translated as the well-being of the daimon. Therefore, it seems paradoxical, how can the who-ness of someone, if according to my hypothesis is embodied, be made manifest after someone's death? In order to solve this paradox, or at least to make sense of it, I will investigate first into the Arendtian meaning of eudaimonia and daimon and then into the Heideggerian meaning of Befindlichkeit, in order to understand how and why she made a connection between the two.

In The Human Condition, Arendt compared the who-ness of someone to a daimon. According to her, we cannot control the way we appear to others, rather, "the 'who', which appears so clearly and unmistakably to others, remains hidden from

\footnotetext{
${ }^{5}$ German version of The Human Condition.
} 
the person himself, like the daimon in Greek religion which accompanies throughout his life" (Arendt, 1998: 179). The relationship between daimon and eudaimonia, as expressed by Arendt, is closely related to the Heideggerian account of it. In Parmenides, Heidegger stressed that " $\varepsilon \dot{v} \delta \alpha \iota \mu o \nu i \alpha$ [eudaimonia] means the holding sway in the appropriate measure of the ' $\varepsilon v$ '-the appearing and coming into presence of

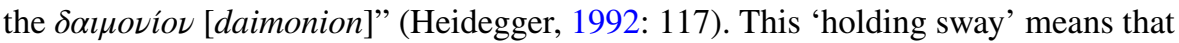
human beings are eudaimon "if they are properly attuned to Being" (Tchir, 2017: 74). It is, in Arendt's words, "a lasting state of being" (1998: 193), lasting after the

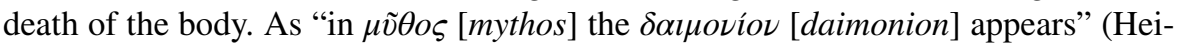
degger, 1992: 117), it is the mythos, the story or the myth left behind that gives the daimon its unchangeability (bleibende), that gives the daimon its immortality. Moreover, Arendt explained that "this daimon [...], this personal element in a man, can only appear where a public space exists" (Arendt, 1968: 73). It represents "the non-sovereign nature of self-disclosure and its retrospective, narrative unfolding" (Tchir, 2017: 74). As Arendt and Heidegger hold it, the daimon is immanent to the actor, it is a part of the who-ness, it "is not a "spirit dwelling somewhere within the breast" (Heidegger, 1992: 117). Rather it is the ungraspable part of what I call the embodied who. It is a way to make the embodiment exist politically. However, it could be argued that Arendt's use of eudaimonia expresses the unchangeable feature of identity rather than its embodiment. Indeed, the daimon is not embodied as such. This is why I will now focus on the Heideggerian Befindlichkeit, which, I will argue, is embodied, to highlight Arendt's use of it.

In Being and Time, the word Befindlichkeit that could be translated as mood or feeling goes against our traditional understanding of what feelings are. Heidegger stressed the fact that Befindlichkeit is "prior to all psychology moods" (1962: 172). Rather, his understanding of 'mood' has something to do with truthfulness. It is then opposed to the common understanding of emotions as interfering truth. Heidegger argued that Befindlichkeit has three main features, "the disclosing of thrownness [..., the current disclosing of Being-in-the-world as a whole [and] a more penetrating understanding of the worldhood of the world" (Heidegger, 1962: 176). Basically, the first feature of Befindlichkeit must be understood as the finding of oneself (sich befinden) in its thrownness or its facticity. The Dasein (Being-there) makes the experience of itself through the experience of its situation, its 'there' (Das). The 'thrownness' refers to the very experience experienced by the Dasein in its openness to itself. However this openness implies the closing of the whence and the whither, which "remain in darkness" (Heidegger, 1962: 173). It means that the Dasein is thrown in a world with no prior knowledge but it just experiences its Dass (that-itis), its facticity, which means the experience of oneself in the mood or state-of-mind that-it-has. Then, in Befindlichkeit, there is the experience of thrownness, "the Being of the 'there' is disclosed moodwise in its 'that-it-is"' (Heidegger, 1962: 173; my emphasis).

Regarding the second feature, Heidegger highlighted that a mood assails us, 'it comes neither from 'outside' nor from 'inside', but arises out of Being-in-theworld, as a way of such Being" (1962: 176). Because Being-in-the-world as a whole has already been disclosed, it is the condition that "makes possible first of all to direct oneself towards something" (Heidegger, 1962: 176). In short, for Heidegger, 
Befindlichkeit is a mode of openness of the being-in-the-world, it is the "fundamental" (Dubois, 2000: 51) 'how' of the disclosedness of Dasein. In other words, Befindlichkeit is the very disclosedness in which the world is present for me, as a whole. Every experience of the world is disclosed in a mood, "we are never free of moods" (Heidegger, 1962: 175).

The third feature concerns the within-the-world things or the other beings that we encounter. However, in order to encounter other beings, we need to be affected; our concern has "the character of becoming affected in some way" (Heidegger, 1962: 176). Indeed, as Heidegger explained, we do not first arrive in a world and then encounter other beings, rather Dasein is always a being-with, which means that what it is, is characterized by its relation to beings. To summarize, Befindlichkeit is the openness of oneself through its thrownness, the openness of the world as a whole and the openness of the being-with in its being-affected (Betroffenwerdens). Moreover, it must be emphasized that Befindlichkeit is not a cognition nor a reaction, rather it is prior to them, it is what makes a reaction possible. It is then revelatory and constitutive of one's relation towards beings.

Concerning the translation of Befindlichkeit, I follow Christos Hadjioannou who put that the term 'disposition' is more suited and is "the best option for translating Befindlichkeit" (2019: 100). Indeed, Befindlichkeit is "more than a passive being affected: it also about having a comportment, in the sense that it requires a certain, even minimal, (relational) enactment that relates to an other" (Hadjioannou, 2019: 100; his emphasis). Accordingly, it could be assimilated to Arendt's view on plurality, even if Heidegger makes it start from the viewpoint of Dasein and self-understanding, but I will discuss this point later. Heidegger's concept of Befindlichkeit as disposition is related to the $\delta \imath \alpha \dot{\alpha} \theta \varepsilon \sigma \iota \varsigma$ (diathesis), which was coined by Aristotle in his Metaphysics. For him, a disposition is "the arrangement [taxis] of something with parts in terms either of its place [topos], or of its potentiality [dunamis] or of its form [eidos]. Some sort of position has to be involved, as indeed the very word disposition suggests" (Aristotle, 2004a, 2004b: 141, 1022b). Aristotle also explained that a disposition is "disposed well or badly" (2004: 141, 1022b). In that sense, it could hypothetically relate to being as a who (well) or as a what (badly) for Arendt, but I will explore this possibility in the following sections. Moreover, Heidegger coined Befindlichkeit in relationship with Stimmung (mood), as every disposition is determined by a stimmung. These attunements or moods which determine our disposition can be enlightened by Heidegger's interpretation of the Aristotelian Pathos. In Heidegger's philosophy, "pathos leaves the narrow domain of psychology and is instead situated within the broader domain of life and its movements" (Oele, 2012: 7). It is an essential movement of being at "the center of the fundamental changes affecting a living being's existence" (Oele, 2012: 9). In other words, Pathos is a mode of being disposed. In De Anima, Aristotle discussed the pathos, the affections of the soul, as a phenomenon that encompasses both body and soul. Indeed, it seems "to be the case that with most affections the soul undergoes or produces none of them without the body" (Aristotle, 1986: 128, 403a). Similarly, Heidegger emphasized the connection of the body and the pathos, as "our being gripped by such and such a $\pi \alpha \dot{\theta} \theta$ os [pathos] does not come exclusively from what befalls us, but the $\gamma \varepsilon \dot{\varepsilon} \nu \sigma 1 \varsigma$ [genesis] of $\pi \alpha \dot{\theta} \theta \eta$ [páthê] is also given by corporeality" (Heidegger, 
2009: 136). Therefore, the pathos is a mode of being that is also given by its corporeality. The living human being is an embodied being in the world. For Heidegger, pathos is "the being-taken of human being-there in its full bodily being-in-theworld" (2009: 132) Hence, Befindlichkeit makes manifest the relationship between pathos and hexis. ${ }^{6}$ For Heidegger, the hexis is "the determination of the genuineness of being-there in a moment of being-composed as to something" (2009: 119; Heidegger's emphasis). Here, the genuineness refers to the authenticity of the Being of Dasein. Hence, Befindlichkeit puts pathos and hexis together as pathos is what is made manifest, what makes us visible, embodied, in hexis. It reveals the comingto-be; embodiment is the condition for the being to come to be, or what Heidegger and Arendt respectively called, a disclosure of being or of the 'who'. In other words, pathos is the manifestation of the wellness or badness or what is disposed, then of its authenticity or not.

After this Heideggerian digression, I can now come back to Hannah Arendt and her use of Befindlichkeit. As I put above, Arendt associated Befindlichkeit with the word bleibende to mark the unchangeable character of identity, then, she is not referring to a passing mood. Following Heidegger, she uses Befindlichkeit to talk about the 'how' of the Being-in-the-world, the 'how' of our appearance in the world before others. Indeed, as being and appearing coincide, being-in-the-world also means appearing-in-the-world. However, Arendt does not view Befindlichkeit from the viewpoint of Dasein. As Sophie Loidolt (2018) put it, the specificity of Arendt's phenomenology is to place plurality as the core phenomenon instead of Dasein. Therefore, Befindlichkeit is to be seen from the perspective of plurality. Arendt "takes the perspective of the worldly appearing of this 'how' of existence, which appears to others as my unique being-in-the-world" (Loidolt, 2018: 210), then, it concerns the disclosure of the 'who'. For Arendt, Befindlichkeit does not mean a givenness to myself, a finding of oneself. Rather, it concerns one's givenness to others. According to the Arendtian account of Befindlichkeit and in respect to the Heideggerian account as well, there is the possibility of an Arendtian political phenomenology of the body that appears. In regards to the Heideggerian embodied Befindlichkeit, I will argue in the next section that political action is embodied and made manifest through a pathos, a hexis and an ethos of action.

\section{The Embodiment of Action}

In this last section, I will show what I think to be Arendt's account of hexis in what Sophie Loidolt calls the excellence and the location thesis (2018: 130). Thereafter, I will focus on a possible account of Arendt's pathos and ethos. I will argue that Arendt gave a political account of pathos and that what she called 'political principles' are the ethos of action.

According to Sophie Loidolt, the excellence thesis is best expressed by Arendt when she stated that "no activity can become excellent if the world does not provide

\footnotetext{
${ }^{6}$ Another term for 'disposition' in Aristotle's Metaphysics.
} 
a proper space for its exercise" (Arendt, 1998: 49; Loidolt, 2018: 133). On the other hand, the location thesis refers to the elementary meaning of the private and the public which "indicates that there are things that need to be hidden and others that need to be displayed publicly if they are to exist at all" (Arendt, 1998: 73; Loidolt, 2018: 133). For instance, I argued in the beginning of this article that the biological or laboring body should stay hidden, it should not appear in public. On the contrary, action should appear in public to have a political existence. Here, the emphasis put on should and should not shows that, for Arendt, it does not mean that a specific activity cannot appear in public as such. Labor can appear in public but it should not. The should/not must be taken as an 'in order to,' in order for the becoming to $b e$. For instance, in order for plurality to be politically significant, it must appear in public in front of others. If it does not, this plurality becomes friendship, as Sophie Loidolt put it (2018: 141). Accordingly, I put that this Arendtian account of the location of an activity refers to the Heideggerian understanding of hexis.

As I explained above, the hexis is "the determination of the genuineness of beingthere in a moment of being-composed as to something" (2009: 119; Heidegger's emphasis). The authenticity of the Dasein, for Arendt, is to be found in a specific disposition or hexis. According to her, authenticity depends on the formation of plurality as a political 'we'; it is then based on an activity. Moreover, the authenticity of plurality is related to its visibility but also "on how the activity is realized" (Loidolt, 2018: 223; her emphasis). Hence, the hexis is a specific disposition in which the becoming authentic is possible or not. Its stability depends on the activities and their actualization, even if a hexis can change precisely because of the pathos. In other words, the being-in-the-world is always a being-disposed-in-the-world. However the character of this being disposed, its authenticity or not, depends on the becoming-to$b e$ of this being. To illustrate this, I suggest to come back to the distinction I made between an actress (what) and Phaedra (who). To be-Phaedra or to be-an-actress depends on the 'how' of the becoming to be. Being-Phaedra means to be-disposed in a certain way that is not the same as being-an-actress. The hexis is not the same because of the becoming-to-be, or the pathos. The question could be put differently as, what makes the shift of disposition from what-ness to who-ness? First, pathos is related to authenticity and inauthenticity which means as a way to be disposed in an authentic way or not. Being disposed as a 'what' or as a 'who' has something to do with the authenticity of our disposition. In other words, the authenticity of Befindlichkeit. Indeed, a "pathic movement can lead to destruction, but can also mean the coming to fruition and full actualization of something" (Oele, 2012: 12). To be disposed in an authentic way for the actress is a way to become Phaedra. The actress fully becomes who she is, Phaedra, through acting. However, if the performance is judged as bad, the pathic movement leads to the destruction of Phaedra. Then, to follow Arendt's claim, the "unchangeable identity [bleibende Befindlichkeit] of the person, though disclosing itself intangibly in act and speech, becomes tangible" (Arendt, 1998: 193). Who someone is refers to its authentic hexis that is achievable through a pathic movement. The pathos is an embodied movement towards authenticity or not. Accordingly, I suggest that the body, is the first condition of politics, because this movement is what expresses the uniqueness of the 'who' as one of the condition of plurality. 
For Arendt, the presence of others is required for a political action to be remembered (Arendt, 1998). These others can make who one is and make one's action "grasped as palpable entity only after it has come to its end," when one is "leaving behind nothing but a story" (Arendt, 1998: 193). However, when it comes to the question of the body, one could argue that action is embodied within the pathic movement, within its very performance, but that the remembrance of action makes the body vanish. It would mean that within the story, the actor is a disembodied actor. Yet, as I suggested above, corporeality is the first condition of politics as it makes possible the uniqueness of the 'who'. Therefore, the question should be, what bodily presence remains after the performance of action? What bodily presence, what embodiment remains in the story? I suggest that the body leaves an ethos, or rather, takes the form of an ethos once the action is done. I put that within the story, the trace of the embodied action is an ethos that is illustrated by what Arendt called 'political principles'. It implies that politics would not be meaningful without its corporeality which enables the creation of an ethos.

Hannah Arendt's concept of political principle is not clearly described in her work but rather disseminated. In What is Freedom, she argued that principles are what make action spring, they are the originary power of action (Arendt, 2006: 152). In On Revolution, she stressed that principles guide the action, they have a guiding power (Arendt, 2016: 120). Finally, in The Promise of Politics, she emphasized their "organizing power" (Muldoon, 2016: 122), their relationship to political community or plurality. Moreover, she added that these principles become "fully manifest only in the preforming act itself" (Arendt, 2006: 151). A principle has something to do with the performance of the action, it is, what first sets action into motion (Arendt, 2006: 194). Furthermore, these principles that inspire action are not psychological emotions or "empirical desires and motivations" (Muldoon, 2016: 123). They cannot be assimilated to any goal to follow. Rather, they are general like the love of equality or honor. I believe that the Aristotelian distinction between $\dot{\alpha} \rho \varepsilon \tau \dot{\eta}$ (arete) and $\tau \dot{\varepsilon} \chi \nu \eta$ (techne), or between virtue and craft/skill is underpinned in the distinction between means-end goal and inspiring principles. For Aristotle, "works of art have their merit in themselves" while virtuous act (arete) depends on how the agent is acting (Aristotle, 2004a, 2004b: 37, 1105a25). In Homer, the arete is the attribute of the hero and their courage (Finkelberg, 1998). In other words, it is what is made manifest in the performance of action and what guides the action itself. The similitude between Arendt's notion of principle and the arete is also visible since she compared the principles to the Machiavellian's notion of virtu, which is inspired by the arete (Ball, 1994). Thus, principles are to be understood in the sense of arete as they inspire action rather than they prescribe it.

Another important point is that for Aristotle, the arete is one of the three categories of ethos (Aristotle, 1991). This ethos does not belong as such to the speaker but it appeals to the audience to judge its credibility. Arendt also highlighted that principles are criteria through which the action of the actor can be judged (2005: 65). In other words, "the two [deed and principle] appear together simultaneously in the public realm in which they can be interpreted and judged" (Muldoon, 2016: 125). Additionally, Arendt emphasized that principles are immanent, which means that they belong to the time and space of their appearance. This 
immanence makes them "manifest in the world as long as the action lasts, but no longer" (Arendt, 2006: 151). However, because principles also are standards of judgment, they can be remembered. An action is judged in the light of these principles as a remembrance of past political actions. Therefore, because principles inspire and guide the action of the doer, it is through them that the who-ness of the actor becomes manifest, its ethos. In other words, a principle, in the sense of arete, guides the actor and makes manifest who the actor is. In Heraclitus's words " $\tilde{\eta} \theta o \varsigma \dot{\alpha} \nu \theta \rho \omega \pi \omega \delta \alpha i \mu \omega \nu$ [the ethos of man is its daimon]" (2004: 310). Actually, it is precisely, this account of ethos that Arendt emphasized in her note from February 1956 (Arendt, 2002: 760). The daimon refers to the political principles that are made manifest in the ethos.

Accordingly, I submit that principles are what inspire and guide the pathic movement of the actor, disclosing who someone is, in an authentic hexis. The pathic movement, when one is acting, is the embodiment of a principle that results in a manifestation of who someone is; which means a manifestation of their being-disposed-in-the-world. Thus, I put that the immanence of the Arendtian principles is not just related to their spatiality and temporality but also to their embodiment. What differentiates a principle from a norm or a rule to follow is its embodiment, which gives a principle its distinctness. The generality or universality of a principle means that it can possibly be embodied in a different way by men and women of action without losing their distinctness. In other words, it is the embodiment that enables the passage from a general arete to a specific ethos-or daimon, without losing the spirit of the former. An heroic Achilles is not the same as an heroic Ulysses. Even if they both are heroic, their way of being heroic is not the same. They embody heroism in a different way. It is the embodiment that allows principles to be actualized, because if they were not, every new act would be subsumed under an old fixed category-Ulysses is heroic like Achilles and not in himself. Therefore, when I put that corporeality is the condition of politics, I mean that it is the condition of plurality because of its requirement to distinctness. To put it differently, one's embodied pathic movement is the condition of one's distinctness, therefore, of politics.

Finally, throughout this article, I explained why the thesis of the antipolitical Arendtian body cannot be accounted for the only Arendtian understanding of the body. Indeed, through an interpretation of her use of Befindlichkeit to define the who-ness of someone, I showed that the body plays a conditional role in Arendt's theory of action. More precisely, my point was that what can be seen as an evidence-we need a body to move, then, to act-is actually justified in Hannah Arendt's philosophy. The title of this article mentions a hidden phenomenology of the body, I am not sure yet if the word 'hidden' is appropriated or should be replaced by 'implicit'. However, the Arendtian account of the body that I have described could be characterized as a politicisation and pluralization of the Heideggerian Befindlichkeit. While for Heidegger Befindlichkeit was the finding of oneself to itself, for Arendt it is the finding of oneself to others. Even if I agree with Sophie Loidolt that Arendt put plurality is the core phenomenon of her phenomenology rather than Dasein, yet, my aim was to show that the body plays an 
important and conditional role in it. In other words, my goal was to emphasize the conditional role that the body plays in Arendt's theory of action.

Open Access This article is licensed under a Creative Commons Attribution 4.0 International License, which permits use, sharing, adaptation, distribution and reproduction in any medium or format, as long as you give appropriate credit to the original author(s) and the source, provide a link to the Creative Commons licence, and indicate if changes were made. The images or other third party material in this article are included in the article's Creative Commons licence, unless indicated otherwise in a credit line to the material. If material is not included in the article's Creative Commons licence and your intended use is not permitted by statutory regulation or exceeds the permitted use, you will need to obtain permission directly from the copyright holder. To view a copy of this licence, visit http://creativecommons.org/licen ses/by/4.0/.

\section{References}

Arendt, H. (1968). Men in dark times. Harcourt.

Arendt, H. (1978). The life of the mind. Vol 1. Thinking. Harcourt.

Arendt, H. (1994). Essays in understanding, 1930-1954. Schocken Books.

Arendt, H. (1998). The human condition (2nd ed.). University of Chicago Press.

Arendt, H. (2002). Journal de pensée (1950-1973). Seuil.

Arendt, H. (2005). The promise of politics. Schocken Books.

Arendt, H. (2006). Between past and future. Penguin Classics.

Arendt, H. (2016). On revolution. Faber Modern Classics.

Arendt, H. (2018). Thinking without a banister. Schocken Books.

Aristotle. (1986). De anima (On the soul). Penguin Classics.

Aristotle. (1991). The art of rhetoric. Penguin Classics.

Aristotle. (2004a). Metaphysics. Penguin Classics.

Aristotle. (2004b). The Nicomachean ethics. Penguin Classics.

Augustine. (2003). The city of God. Penguin Classics.

Ball, T. (1994). Reappraising political theory: Revisionist studies in the history of political thought. Oxford Clarendon Press.

Benhabib, S. (2003). The reluctant modernism of Hannah Arendt. Rowman \& Littlefield Publishers.

Betz-Hull, M. (2002). The hidden philosophy of Hannah Arendt. Routledge.

Borren, M. (2010). Amor mundi: Hannah Arendt's political phenomenology of world. F \& N Eigen Beheer.

Connolly, W. (1997). A critique of pure politics. Philosophy \& Social Criticism, 23(5), 1-26.

Dubois, C. (2000). Heidegger. Introduction à une lecture. Éditions du Seuil.

Finkelberg, M. (1998). Timē and Aretē in Homer. The Classical Quarterly, 48(1), 14-28.

Hadjioannou, C. (2019). Heidegger on affect. Palgrave McMillan.

Heidegger, M. (1962). Being and time. Blackwell Publishing.

Heidegger, M. (1992). Parmenides. Indiana University Press.

Heidegger, M. (2009). Basic concepts of Aristotelian philosophy. Indiana University Press.

Lefort, C. (2002). Thinking with and against Hannah Arendt. Social Research, 69, 447-459.

Loidolt, S. (2018). Phenomenology of plurality. Hannah Arendt on political intersubjectivity. Routledge. Merleau-Ponty, M. (2010). Euvres. Quatro Gallimard.

Muldoon, J. (2016). Arendtian principles. Political Studies, 64, 121-135.

Oele, M. (2012). Heidegger's reading of Aristotle's concept of pathos. Philosophy, Paper 18.

Plato. (1969). The collected dialogues of Plato. Princeton University Press.

Schoonheim, L. (2019). The productive body: Rereading Hannah Arendt's critique of corporeality and introspection. Philosophy Today, 63, 471-489.

Taminiaux, J. (1997). The Thracian maid and the professional thinker. State University of New York Press. 
Tchir, T. (2017). Hannah Arendt's theory of political action. Daimonic disclosure of the 'who.' Palgrave McMillan.

Tierney, T. (1993). The value of convenience. State University of New York Press.

Villa, D. (1995). Arendt and Heidegger: The fate of the political. Princeton University Press.

Young-Bruehl, E. (1984). Hannah Arendt. Yale University Press.

Zerilli, L. (1995). The Arendtian body. In B. Honig (Ed.), Feminist interpretations of Hannah Arendt. Pennsylvania University Press.

Publisher's Note Springer Nature remains neutral with regard to jurisdictional claims in published maps and institutional affiliations. 